\title{
THE US-CHINA TRADE WAR: CAUSE-EFFECT ANALYSIS
}

\author{
Irina V. Onyusheva \\ Turan University, Almaty, Kazakhstan \\ Stamford International University, Bangkok, Thailand \\ Cherry Thinn Nain \\ Aung Lin Zaw \\ Stamford International University, Bangkok, Thailand \\ Strategy First Institute, Yangon, Myanmar
}

The US-China trade war has been considered one of the urgent issues in today's international trade. In fact, this is a trade war where top two largest world economies participate. In this paper, we have made an attempt to describe and explain the motives behind this trade war along with the potential threats, causes and effects for the world economy. Comparative macroeconomic analysis of the involved countries has been also conducted. Possible retaliation of China and other countries to the US' increasing in tariffs on imported goods, protectionism and deficit issues in the US are discussed in the first part of the paper. The authors focus on the potential threats and effects that this trade war may have on the world economy from the political economy point of view. Authors' vision on the future prospects of the current situation is also presented.

Keywords: trade relations; trade war; USA; China; cause-effect analysis.

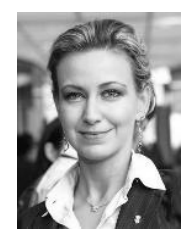

Irina Onyusheva

Dr., Prof., Turan University, Almaty, Kazakhstan; Stamford International University, Bangkok, Thailand Interests - Economics, Strategic Management, Formation, ensuring and increasing economic competitiveness on both micro- and macro- levels; Human Capital development; HR Management; Knowledge Economy; Knowledge Management; Project Management; Management in Education

E-mail: dr.irina.onyusheva@gmail.com

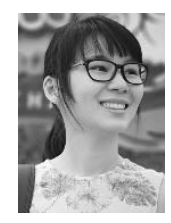

Cherry Thinn Naing

Stamford International University, Bangkok, Thailand; Strategy First Institute, Yangon, Myanmar, International MBA Program

Interests - International Business Management, Strategic Management, HR Management

E-mail: cherry_thinn_naing@gmail.com

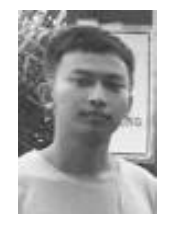

Aung Lin Zaw

Stamford International University, Bangkok, Thailand; Strategy First Institute, Yangon, Myanmar, International MBA Program

Interests - International Business Management, Strategic Management, HR Management

E-mail: aung_lin_zaw@gmail.com 


\section{THE US-CHINA TRADE WAR}

\section{Introduction}

Trade war is an economic conflict when one country attacks another by raising tariffs or trade barriers on imports (Trade War, $\mathrm{n} / \mathrm{d}$ ).

The trade war of the US and China means the ongoing introduction of tariffs on goods traded between these two countries. Once Donald Trump became the US President, the American government nearly immediately imposed tariffs on steel and aluminum imported from China, Canada and the EU countries (Tan, 2018). It has been commonly stated that the main reason behind these new tariffs on steel and aluminum at the US market was the fact that cheap steel from abroad has interrupted the development of the US steel industry, thus resulting in the loss of many American jobs. Therefore, the country's revenues from this industry also became much lower (Aleem, 2018). The Americans understand very well that this can be a disadvantage for them in the long run as steel is very important in the nation's infrastructure, it has also become a vital component in economic security of this nation. But when it comes to the case between China and the US specifically, there are also much broader scopes within which these two countries have been competing, this is not just competition about tariffs on goods from China. Still, one of the main reason behind this trade war in question is Trump' protectionism over American industries. Imposing additional tariffs on the goods imported from China is seen as a means of limitation of Chinese products and reduction of the trade deficit between these two countries (Pong, 2018).

When the US Government announced that they will impose $25 \%$ tariff on every 50 billion to 60 billion goods imported from China, including information and communication technologies, aerospace and other machineries, China, in their turn, has also put tariffs on a wide range of the US products, including wine and apples, this has been seen as quite a logical response (Lobosco, 2018). Later on, the US again announced more tariffs on about 1300 Chinese products, and not just on steel and aluminum. Literary several hours later, China came out with another idea of tariffs' rise -- this time on Boeing planes, one of the most important industries for the USA. In this way China was sending the message that they would fight back at any cost against the United States if it keeps to the idea of protectionism. This was the very beginning of what we call now the trade war. Interestingly here, this was is going to have side effects for both involved countries and other third-party countries too, actually.

In a nutshell, Trump's protectionism seems to be the starting point in the economic conflict between China and the US. And today this conflict is surely imposing several very different political, economic and social influences globalwide.

\section{Cause-Effect Analysis of the Trade War}

Making use of the classical cause-effect analysis diagram on the current US-China trade war, we can analyze the key factors which have initiated and contributed to this war.

\section{The US Policy of Protectionism}

Protectionism means "trying to implement restrictions like tariffs on imported goods to boost a country industry and prevent it from severe foreign competition" (Amadeo, 2018). If we look at the US-China trade war case, imposing tariffs on steel and aluminum means that Trump wants to boost the development of local industry of steel and aluminum production by 
restricting China imports in the same categories. Trump stated he will impose a $25 \%$ tariff on all steel imports and $10 \%$ on aluminum which is not easy to accept for Chinese steel and aluminum industries (Bryan, 2018).

The American administration claims that the US depends too much on foreign countries for its metal, and as a result, they will not be able to make enough weapons and vehicles if a war should break out (Swanson, 2018). In other words, the US gets a larger share of its steel, aluminum and other metals from other countries. If import of these goods are restricted, consumption of local steel and aluminum might rise along with more efficient use of resources, which generally means the empowerment of the whole industry resulting in the creation of more jobs and increase in income tax volume for the country.

In theory, imposing an additional financial limitation on foreign steel and aluminum is expected to mean that the US companies will buy local steel instead. Then, the cost of steel and aluminum can rise at the US markets as there will be less offers imported from other countries. Greater demand for the goods will push up the price which will result in more profit for the local steel makers.

The idea of protectionism might be good for the steel and aluminum industry, but when we look at other industries and the related consequences for them, we can see that such actions might affect other industries rather badly. For example, for all the companies that need raw materials from other countries, including car building and airplanes construction, such changes would only mean they will be blown by the costs rising up due to the response of other countries to the protectionism actions carried out by Trump. Eventually, this can lead to the increase in car prices and air ticket costs in the US as the spending in these industries (and some other) will go up. In such a way the idea of protectionism can affect much more people than initially expected - those working in the related industries and also those using products and services of these industries.

As we have mentioned above, China has imposed an additional tax on the US agricultural and industrial products -- from soybeans, cotton and pork to planes, cars and steel pipes. China could also tax US technology companies, including Apple. It would be logical to assume that Apple, in their turn, would be forced to raise prices. So, in many ways, the very idea of American protectionism can affect millions of other consumers around the world since they also would have to face higher prices for the US-related products. Indeed, protectionism may boost the development of steel and aluminum industries in the US, but it may also change the prices for other products. This may result in retaliation on the side of other countries, in relation to the US.

\section{Trade Deficit}

Trade deficit has become one of the main reason behind the outbreak of this trade war. It means imbalances between how much a country buys from another country and how much it sells to this other country (Segal, 2018). The US has a large amount of trade deficit with China, this deficit stood at about $\$ 375$ billion last year which means that the amount of the US imports from China exceeds the export to China by $\$ 375$ billion. And this fact clearly makes President Trump unhappy.

In total, the US trade deficit was $\$ 568.4$ billion in 2017 , thus increasing from $\$ 504.8$ billion back in 2016 (Aversa, 2018). It exported goods and services for $\$ 2.329$ trillions while importing only for $\$ 2.895$ trillion. Back in 2013 , the deficit was $\$ 478$ billion and it was considered to be very high, however, the deficit as of 2017 turned out to be much higher. 


\section{THE US-CHINA TRADE WAR}

One of the reasons for this is that USD becomes stronger, and strong dollar, in turn, makes export more expensive and import cheaper (Econ, 2017). The highest deficit was recorded in 2006 and it was $\$ 762$ billion. Compared to this, the trade deficit as of 2017 was less which means export grows faster than import, at least as compared to 2006. This is a good sign for the US market of jobs and many local businesses; still, the deficit as of 2017 is still quite high.

It would be worth noting here that automobiles and consumer products are the primary drivers of this trade deficit. Back in 2017 the US imported TV sets, clothing, generic drugs and various household items for the sum of $\$ 602$ billion while exporting only for $\$ 198$ billion of consumer goods (Sahadi, 2017). When it comes to the automobile sector alone, the US export only $\$ 158$ billion worth of automobile and parts while importing $\$ 359$ billion in total (Long, 2018).

Thus, it comes as no surprise that the President Trump wants to reduce the deficit and is favoring protectionist measures. To be able to reduce this deficit, he plans to control imported goods from other countries by imposing more tariffs on them so that to boost local industries and companies in their export activities. The core aim here is to reduce the imbalances between exports and imports of goods which will result in job growth and increase in revenues in the United States of America.

\section{OBOR}

Chinese President $\mathrm{Xi}$ Jinping also has most ambitious foreign policy vision and economic initiatives. One of them is known as the One Belt One Road (also known as the Silk Road Economic Belt, or the 21st Century Maritime Silk Road). This programme has been long considered as one of the vitally important projects for the development of the whole Asia in terms of trade, infrastructure, investment and economic corporation overall.

The United States have been a superpower for a long time and in almost every field, economy and military sector in the first place. However, despite of having very much different economic principles, China today is also implementing its global strategy and is seen by many as an emerging superpower challenging the role of the US.

First of all, Trans-Pacific Partnership, a trade partnership initiated back in 2015, is strategically used today by the United States as a leverage in Asia-Pacific cooperation as long as Asia-Pacific policy of the United States is counterbalancing China's rising power. The Belt Road Initiative may become one of China's strategies extending its political influences by investing in them and thus connecting them globalwide, except for the United States. Moreover, TPP is already affecting quite positively through its economic advantages, while BRI might soon become Chinese winning strategy in this fierce competition.

Secondly, the Belt Road Initiative can effectively weaken the United States economically. China is an emerging market of a truly global scale globally and there are many strategies behind its huge project called BRI. For that, United States is strongly opposing this initiative because it will surely become a threat for them, and sooner than expected.

Last but not least, BRI may have a significant effect on the ongoing trade war between the United States and China. We are of the opinion that the whole trade war from the very beginning has the key intention to slow down China's emerging economic influences upon the neighbouring and other regional countries. 


\section{Political Conflicts}

The ongoing trade war will have many impacts on international markets across different economic sectors. $25 \%$ tariff on steel imports to the US will affect all the countries which import steel to the US; mainly Canada, Brazil and South Korea, and also European countries and Russia (Figure 1).

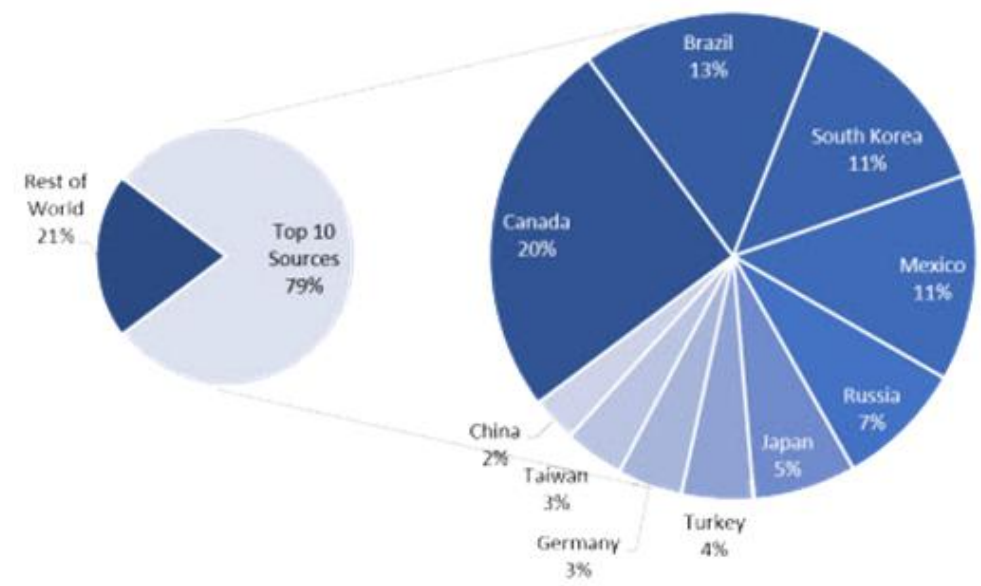

Figure 1 - Shares in the US Steel Imports: Top 10 Sources as of 2018 (Source: Krishna, 2018)

Therefore, effects from this recently tariff will definitely impact Canada, many EU members, South Korea and Russia, whereas the end consumers of steel and aluminum back in the US will face much higher pricing.

\section{Intellectual Property Theft}

Another interesting reason for this trade war is because the US wanted to retaliate against China for their improper intellectual property practices. According to the IP Commission Report, it has been relatively recently estimated that the costs due to the theft of trade secrets and IP rights can be as high as $\$ 600$ billion annually (Update to The IP Commission Report on The Theft of American Intellectual Property: Reassessments of Challenges and United States Policy, 2017). For years, the US claimed that many trade secrets of its own as well as unique technologies were stolen by China (Board, 2018). Therefore, today's trade war can be considered as some sort of retaliation following the numerous concerns about Chinese intellectual property theft. In this context specifically, the key motivation of the US concerns national economic security in its long-term perspective.

\section{Timeline of the US-China Trade War and the Current Actions}

The ongoing US-China trade war started in 2018, and its timeline was briefly as follows (Trump tariffs: the US escalates trade threats to China, 2018):

January 2018: the US government announced new tariffs on the import of solar panels and washing machines;

March 2018: the US government announced that it is planning to impose $25 \%$ tariff on steel and $10 \%$ on aluminum imports; 


\section{THE US-CHINA TRADE WAR}

April, same year: China retaliated back by announcing tariffs' rise (from $15 \%$ up to $25 \%$ ) on the US imports;

6th of July 2018: the US administration confirmed they were seriously planning to impose $25 \%$ more on the tariff on steel imports and $10 \%$ for aluminum imports. This radical change immediately affected around $\$ 34$ bln of Chinese products. By many, this was seen as the only real cause why President Trump has started this trade war;

10 July 2018: the US announced again they will impose a 10\% tariff on US\$200 Bn of Chinese-made products (quite a wide range of products, from food to electronics). This announcement came into effect as of 30 August 2018 (China's response to the trade war can hit US technology industry where it hurts most, 2018).

The next and quite logical step in the trade was currency war. As of YTD 2018, Chinese yuan value is decreasing significantly to 6.80 per 1 USD (Kuen, 2018). This brings along the financial impact on the entire market. Other Asian countries also encounter great difficulties and financial pressure because all their central banks are strongly dependent on China, through various financial mechanisms and tools.

Products impacted have been mainly from the US \& China. The effect from Chinese tariffs has been especially serious for the aircraft, other vehicles, textiles and apparels. On the other side, in Chine the effect from the US tariffs became a serious problem for machinery, electrical equipment, chemicals and metals (Trump tariffs: the US escalates trade threats to China, 2018).

\section{Comparative Analysis between the US and China: Political Economy Portfolio}

Table 1 presents the comparative analysis of the US and China reflecting their political and economic backgrounds.

Table 1 - USA Vs. China: Political Economy Portfolio

(Source: Compiled on the base of DBS Economics \& Strategy, Bloomberg data, 2018)

\begin{tabular}{|c|c|c|}
\hline Indicators & USA & China \\
\hline Political Background & Liberalism & Communism \\
\hline Economic System & $\begin{array}{c}\text { Capitalism/ Mixed } \\
\text { Economy }\end{array}$ & $\begin{array}{c}\text { Command/ Mixed } \\
\text { Economy }\end{array}$ \\
\hline Unemployment Rate & $3.9 \%$ & $3.95 \%$ \\
\hline GDP & 18.57 trillion USD & 11.2 trillion USD \\
\hline GDP Growth rate & $1.6 \%$ & $6.7 \%$ \\
\hline Gross National Income & 18.75 trillion PPP dollars & 21.37 trillion PPP dollars \\
\hline Population & Over 325 mln & Over 1386 mln \\
\hline Military Strength Rating & World 1st & World 3rd (after Russia) \\
\hline Trade & 115.6 billion USD & 462.6 billion USD \\
\hline
\end{tabular}

Political System. On the one hand, the US is the oldest continuous democracy in the world (Lawrence, Martin, 2012) It also has the federal government which is managing the country as a democratic republic. Legislative, executive and judicial branches comprise the infrastructure of this government. 
On the other hand, China is practising the monopoly on power imposed by the Communist Party (Lawrence, Martin, 2012). Such traditional for many Western countries notions as multi-party system, shared power, federal system etc. are not accepted by the party as such.

Obviously, these two political systems are vastly different in both fundamentals and management principles.

Economic System. The Americans adopted capitalism as the core of their economic system from the very first day of their country's functioning. China has opted for the command economy. In simple terms, American economy is based on privately owned enterprises, while publicly owned government enterprises form the basis for Chinese command economy.

Unemployment Rate. Table 1 clearly shows that the rates of unemployment in these two countries are not much different between. However, types of unemployment are very different (structural, cyclical etc.)

GDP. China production is much smaller if measured through GDP. This is not surprising at all since the US is still the world leading economy with no visible competitors as of today.

GDP growth rate. Since China is still considered to be an emerging market, thus, its growth rate is significantly greater than that of the US market which is already mature.

Gross National Income. It is larger in the case of China, however, the difference is not that significant. Both countries demonstrate quite impressive productivity.

Military Strength Rating. Not much difference is seen between China and the USA.

Trade. As of today, the trade deficit is over 300 billion USD. It became the key reason for the current trade war.

\section{Conclusion}

Today's trade war is obviously affecting both the US and China as well as several other, related countries. There is a lot of retaliation on both sides, some of the third parties are also trying to react accordingly. Russia, for example, has managed to gain some benefits from this trade war. If negotiations do not end in any meaningful result, satisfactory for both sides, the US and China will soon be removed from the "league of superpowers". Moreover, they can be easily substituted by such countries as Russia, Japan etc. As of today, several actively developing countries already demonstrate the ambition to become the world leading economies.

Moreover, other impacted countries could come up with some alternative decisions in the attempt to fight/prevent the negative consequences from this trade war for their own economies. For example: (1) monetary policies in relation China's exporters could be radically changed; (2) traders may choose other ways, excluding China from their operations as such; (3) the US may become able to import goods to China through various intermediaries from other countries etc.

\section{References:}

Aleem, Z. (2018). The US-China trade war, explained in under 500 words. Retrieved from: https://www.vox.com/world/2018/7/6/17542482/china-trump-trade-war-tariffs 


\section{THE US-CHINA TRADE WAR}

Amadeo, K. (2018). Trade Protectionism and Its Methods With Examples, Pros, and Cons Retrieved from: https://www.thebalance.com/what-is-trade-protectionism-3305896

Aversa, J. (2018). Retrieved from bea.gov: https://bea.gov/newsreleases/international/trade/2018/pdf/trad0118annual_fax.pdf

Board, E. (2018). A New Front in Trump's Trade War. Retrieved from: https://www.bloomberg.com/view/articles/2018-03-11/china-intellectual-property-andtrump-s-next-trade-war

Bryan, B. (2018). Trump threatens to double down on his trade war with China - and the fight could be about to get ugly Retrieved from: https://www.businessinsider.com/trumpchina-trade-war-tariff-chinese-imports-2018-8

China's response to the trade war can hit US technology industry where it hurts most. (2018). Retrieved from: https://www.scmp.com/business/globaleconomy/article/2154924/chinas-response-trade-war-can-hit-us-technology-industry

Econ, M. (2017). Is the U.S. trade deficit a problem? What is the link between the trade deficit and exchange rates? Retrieved from: https://www.frbsf.org/education/publications/doctor-econ/2007/june/trade-deficitexchange-rate/

Krishna, M. (2018). Where Does the U.S. Import Steel From? Retrieved from: https://www.investopedia.com/news/where-does-us-import-steel/

Kuen, Y. L. (2018). From trade war to currency war? Will RM suffer? Retrieved from: https://www.thestar.com.my/business/business-news/2018/07/23/from-trade-war-tocurrency-war/

Lawrence, Susan V.; Martin, Michael F. (2012). Understanding China's Political System. Retrieved from: https://fas.org/sgp/crs/row/R41007.pdf

Lobosco, K. (2018). Trade war: The US and China just slapped new tariffs on each other. Retrieved from: https://edition.cnn.com/2018/08/23/politics/china-us-tariffs/index.html

Long, H. (2018). Why America's return to $\$ 1$ trillion deficits is a big problem for you. Retrieved from: https://www.washingtonpost.com/news/wonk/wp/2018/04/09/whyamericas-return-to-1-trillion-deficits-is-a-big-problem-foryou/?noredirect=on\&utm_term $=.455 \mathrm{bdcfd} 58 \mathrm{f}$

Philip Wee, Nathan Chow. (2018). CNY: What's going on, where is it going. Retrieved from www.dbs.com.sg:

https://www.dbs.com.sg/treasures/templatedata/article/generic/data/en/GR/072018/180

727_insights_china_cny_whats_going_on_where_is_it_going.xml

Pong, J. (2018). Retrieved from: https://ig.ft.com/us-china-tariffs/

Sahadi, J. (2017). Deficit for 2017 hits $\$ 666$ billion. Retrieved from: https://money.cnn.com/2017/10/20/news/economy/deficit-2017/index.html

Segal, T. (2018). What is a trade deficit and what effect will it have on the stock market? Retrieved from: https://www.investopedia.com/ask/answers/trade-deficit-effects-onstock-market/

Swanson, A. (2018). Chinese Goods May Face 25\% Tariffs, Not 10\%, as Trump's Anger Grows. Retrieved from: https://www.nytimes.com/2018/08/01/business/china-tariffstrump.html.

Tan, H. (2018). Beijing retaliates as new US tariffs kick in on $\$ 16$ billion of Chinese goods. Retrieved from: https://www.cnbc.com/2018/08/23/us-china-trade-war-new-round-ofamerican-tariffs-on-chinese-imports.html

The real reason Trump wants to start a trade war (2018). Retrieved from: https://www.washingtonpost.com/blogs/plum-line/wp/2018/03/02/the-real-reasontrump-wants-to-start-a-trade-war/?noredirect=on\&utm_term $=.4854 \mathrm{ed} 38 \mathrm{a} 4 \mathrm{a} 0$

Trade War (2018). Retrieved from: https://www.investopedia.com/terms/t/trade-war.asp 
Trump tariffs: US escalates trade threats to China (2018). Retrieved from: https://www.bbc.com/news/business-44529149

Update to The IP Commission Report_The Theft of American Intellectual Property: Reassessments of Challenge and United States Policy (2017). The National Bureau of Asian Research. Retrieved from: www.ipcommission.org

Paper submitted

Paper accepted for publishing

Paper published online
17 October 2018

11 December 2018

31 January 2019 